\title{
Activation of the L-arginine nitric oxide pathway in severe sepsis
}

Trevor Duke, Mike South, Alastair Stewart

\begin{abstract}
Aims-To determine in children with sepsis syndrome and septic shock the time course of nitric oxide metabolites: nitrate and nitrite (nitrogen oxides). To determine whether serum concentrations of nitrogen oxides distinguished those children who died from sepsis from those who survived; those who required prolonged inotropic support compared with those who did not; and whether there was any relationship of the levels of nitrogen oxides to markers of tissue perfusion.

Methods-Nitrogen oxides were measured in 30 children with sepsis syndrome or septic shock at admission, 12, 24, and 48 hours. A non-septic control group had serum nitrogen oxides measured at admission. Markers of haemodynamics and tissue perfusion measured were mean arterial pressure, blood lactate, base deficit, gastric intramucosal $\mathbf{p H}$, and del$\mathrm{taCO}_{2} \quad\left(\mathrm{DCO}_{2}\right.$ : the difference between arterial and gastric intraluminal carbon dioxide tensions). Inotrope doses, number of organ systems failing at 48 hours, and outcome as survival were recorded.

Results-Children with sepsis had increased nitrogen oxide concentrations at presentation compared with a group of non-septic controls. Children with organ failure at 48 hours had higher serum nitrogen oxide concentrations than those with sepsis uncomplicated by organ failure at 48 hours. There was no difference in nitrogen oxide when patients were subgrouped according to the receipt of inotropes at 48 hours, and no association with markers of tissue perfusion, or survival. Conclusions-While this study shows that nitric oxide production is increased in sepsis in children, there was a limited relationship with clinically important markers of illness severity and no relationship to survival.

(Arch Dis Child 1997;76:203-209)
\end{abstract}

Keywords: sepsis; nitric oxide; nitrogen oxides; organ system failure.

Institute, St Vincent's

Hospital, Melbourne,

Australia

A Stewart

Correspondence to:

Dr Trevor Duke, Paediatric

Intensive Care Unit, Royal

Children's Hospital,

Flemington Road, Parkville,

Victoria 3052, Australia.

Accepted 6 September 1996 $\mathrm{NO}$ in vivo is difficult because of its short half of guanylate cyclase, has been suggested as therapy for sepsis. ${ }^{2-6}$ While measurement of NO in vivo is difficult because of its short major mediator of pathological vasodilatation in sepsis and septic shock. ${ }^{1}$ Inhibition of NO production using methylated L-arginine ana- life, the stable products of NO oxidation: nitrate and nitrite (nitrogen oxides), measured in biological fluids, have been used as an indication of NO activity. ${ }^{7-10}$ High serum nitrogen oxides have been reported to correlate with the presence of hypotension in sepsis in children, ${ }^{7-9}$ but there is little information on the association of nitrogen oxides and markers of tissue perfusion, survival, and organ failure. $\mathrm{NO}^{-}$ induced vasodilatation and myocardial depression during sepsis has been proposed as mechanisms for the perfusion failure of septic shock, ${ }^{11}$ and reduced responsiveness to catecholamines. ${ }^{12}{ }^{13}$ If this were true children with severely abnormal markers of poor tissue perfusion, such as a high blood lactate and low gastric intramucosal $\mathrm{pH}(\mathrm{pHi}),{ }^{14}$ and those requiring prolonged inotropic support, may have high concentrations of nitrogen oxides. Finding an association between nitrogen oxide concentrations and clinically important outcomes may strengthen the argument for NO modulation as a treatment for sepsis.

\section{Aims and hypotheses}

We tested the hypothesis that serum concentrations of nitrogen oxides are increased in children with sepsis, compared with a control group of children; and that nitrogen oxide concentrations are higher in children who die from sepsis compared with those who survive. We also proposed that there would be a relationship between serum nitrogen oxides and the severity of organ system failure; and between nitrogen oxides and prolonged inotropic support. In addition, we examined the relationship of renal function to serum nitrogen oxides. NO metabolites are cleared by the kidney and it has been suggested that renal function is an important confounding variable when interpreting nitrate and nitrite concentrations. ${ }^{15}$

Methods and statistical analysis

This study was approved by the Ethics in Human Research Committee of the Royal Children's Hospital in Melbourne, and informed consent was obtained from the patients' parents. Children were eligible for inclusion in this study if they were admitted to the intensive care unit with sepsis syndrome or septic shock. The diagnostic criteria of Bone et $a l,{ }^{16}$ modified for children were used. ${ }^{17}{ }^{18}$ The features were clinical evidence of sepsis, with fever (rectal temperature $>38.0^{\circ} \mathrm{C}$ ) or hypothermia $\left(<35.6^{\circ} \mathrm{C}\right)$, tachycardia (heart rate $>95$ th centile for age), tachypnoea (respiratory rate $>95$ th centile for age), hypotension (mean arterial pressure $<5$ th centile for age), and at 
least one of the following manifestations of inadequate organ perfusion or organ dysfunction: altered mentation, metabolic acidosis (arterial $\mathrm{pH}<7.35$ or base deficit $>-5$ ), oliguria (urine output $<1 \mathrm{ml} / \mathrm{kg} /$ hour), or signs of poor peripheral perfusion (poor capillary refill, cyanosis, or diminished peripheral circulation). A blood culture positive for a likely pathogen, or bacterial culture from an otherwise sterile site, was not necessary for the diagnosis. An immature to total granulocyte ratio of greater than 0.2 , or neutropenia, in the absence of positive cultures and other demonstrable cause was considered adequate for the diagnosis. We studied consecutive patients admitted to the intensive care unit over a 12 month period.

Blood was collected for nitrate and nitrite assay at the time of admission and at 12, 24, and 48 hours. Collected blood was immediately centrifuged (Megafuge 1.0, Heraeus Sepatech, West Germany) at 4000 revolutions/ minute for 10 minutes and the separated serum was frozen at $-20^{\circ} \mathrm{C}$. The assay for nitrogen oxides was done within six weeks of the time of collection. Nitrite was assayed by the Griess reaction, which does not detect nitrate. Serum nitrate was therefore converted to nitrite by incubation of $300 \mu \mathrm{l}$ of serum with nitrate reductase (Boehringer Mannheim, NSW, Australia) and NADPH ( $\beta$-nicotinamide adenine dinucleotide phosphate, reduced form, Sigma Chemical Company, St Louis, MO, USA) for 100 minutes at $37^{\circ} \mathrm{C}$. The reaction was terminated by addition of zinc sulphate $(1.5 \% \mathrm{w} / \mathrm{v}$, final concentration) to precipitate protein. The sample was centrifuged at $2000 \mathrm{~g}$ for five minutes at $4^{\circ} \mathrm{C}$ (Sorvall microfuge) and the nitrite was determined in the supernatant. Nitrite concentrations were measured using the reaction of the Griess reagent ( $1 \%$ sulfanilamide/ $0.1 \%$ napthylethylenediamine dihydrochloride $/ 2.5 \%$ phosphoric acid, Boehringer Mannheim, NSW, Australia) with $\mathrm{NO}_{2}^{-}$forming a chromophore. An aliquot of $100 \mu \mathrm{l}$ of sample was added to $100 \mu \mathrm{l}$ of freshly prepared Griess reagent in a microtitre plate. After a five minute period to allow colour development, the absorbance was determined in a Behring plate reader at $570 \mathrm{~nm}$. The concentration of $\mathrm{NO}_{2}^{-}$was quantified by comparison with a standard curve constructed using known concentrations of $\mathrm{NO}_{2}^{-}(0.1-100 \mu$ molar $)$.

Arterial blood lactate, gastric $\mathrm{pHi}$, deltaCO $\mathrm{CO}_{2}$ $\left(\mathrm{DCO}_{2}\right)$, base deficit, mean blood pressure, and serum creatinine were measured at the same four time points. Lactate was measured using an Ectachem 250 analyser (Johnson and Johnson Clinical Diagnostics, USA). Arterial blood gases were measured with an ABL blood gas analyser (Radiometer, Copenhagen). We used the same method to estimate gastric $\mathrm{pHi}$ as described by Krafte-Jacobs et al. ${ }^{19}$ Where possible a Trip adult sigmoid catheter (Tonometrics) was inserted orogastrically. Confirmation of the position of the catheter in the lumen of the stomach was assessed radiographically. Sterile saline $(2.5 \mathrm{ml})$ was infused into the tonometer and a period of equilibration of at least 60 minutes was allowed. The deadspace of $1 \mathrm{ml}$ of saline was aspirated and discarded, and the remaining saline was aspirated for analysis of carbon dioxide pressure. This was done with an ABL blood gas analyser (Radiometer Copenhagen). The gastric pHi was calculated using the modified HendersonHasselbalch equation. A high $\mathrm{DCO}_{2}$ has been proposed as a more specific indicator of poor gastrointestinal perfusion than $\mathrm{pHi}$. The $\mathrm{DCO}_{2}$ was calculated by subtracting the arterial carbon dioxide tension from the gastric intraluminal carbon dioxide tension, the latter of which was measured using the tonometer. Inotrope doses were also recorded.

Outcome measures were mortality; the number of organ systems failing at 48 hours (see table 1); markers of perfusion (blood lactate, gastric $\mathrm{pHi}, \mathrm{DCO}_{2}$, base deficit, and mean arterial pressure); and need for ongoing inotropic support at 48 hours. We used the area under the curve (AUC) for combined serum nitrate and nitrite, as a summary measure, ${ }^{20}$ of NO production. This was compared with the number of organ systems failing at 48 hours after admission, markers of perfusion, and to mortality. The AUC for nitrogen oxides, creatinine, and markers of perfusion failure, were calculated by the following formula (using nitrite as the example): AUC nitrite $=6$ (admission nitrite) $+12(12$ hour nitrite $)+18$ (24 hour nitrite) +12 (48 hour nitrite) (T Byrt, Clinical Epidemiology and Biostatistics Unit, Royal Children's Hospital, personal communication). Definitions of organ systems failure were developed from the literature on age dependent normal ranges for haematological, ${ }^{21-23}$ biochemical, ${ }^{24}$ and physiological values ${ }^{25}$; and adult definitions of organ failure,$^{26}$ adapted to paediatric practice (table 1).

For a non-septic control group we chose children presenting for elective cardiac surgery: the largest group of children who are admitted to our intensive care unit. Although not strictly normal controls, all children were free of clinical and laboratory evidence of infection at the time of surgery. For comparison with this group we used the admission nitrogen oxide concentration in septic and cardiac patients. In the cardiac patients the concentration of nitrogen oxides was measured on blood taken before surgery and prior to exposure to nitrate containing drugs. Many cardiac patients received nitrovasodilators during and after surgery. These agents, glyceroltrinitrate and sodium nitroprusside, act as NO donors, ${ }^{27}$ and would have been a confounding variable in a comparison using area AUC for the first 48 hours of intensive care unit admission.

Normally distributed data are expressed as mean and $95 \%$ confidence interval, with differences in group means compared by Student's $t$ test. Non-normally distributed data were compared using non-parametric tests. The Kruskal-Wallis test of equality of proportions with Sidak's adjustment for multiple comparisons was used to assess the relationship of number of organ system failure with AUC nitrogen oxide concentrations. Correlations between AUC nitrogen oxides and other variables was assessed by regression analysis. A 
Table 1 Definitions of organ system failure

\begin{tabular}{|c|c|}
\hline Cardiac & $\begin{array}{l}\text { Presence of one or more of the following: } \\
\text { MAP (mm Hg) } \\
\quad<30 \text { (neonate- } 3 \text { months old) } \\
\quad<35 \text { (age } 3 \text { months- } 1 \text { year) } \\
\quad<40 \text { (age } 1 \text { year }-6 \text { years) } \\
\quad<50 \text { (>6 years) } \\
\text { Arterial blood pH }<7.25 \text { with } \mathrm{PaCO}_{2}<6.0 \mathrm{kPa} \\
\text { Requirement for inotropes more than } 10 \mu \mathrm{g} / \mathrm{kg} / \mathrm{min} \text { dopamine }\end{array}$ \\
\hline Respiratory & $\begin{array}{l}\text { Presence of one or more of the following } \\
\mathrm{PaCO}_{2}<6.7 \mathrm{kPa} \text { with serum } \mathrm{pH}<7.25 \\
\mathrm{~A}-\mathrm{aDO}_{2}>46.7 \mathrm{kPa} \\
\text { Ventilation index }>30\end{array}$ \\
\hline Renal & $\begin{array}{l}\text { Requirement for renal replacement therapy, for example peritoneal dialysis, } \\
\text { haemofiltration and presence of one or more of the following: } \\
\text { Urine output: }<0.5 \mathrm{ml} / \mathrm{kg} / \text { hour for } 4 \text { consecutive hours or }<300 \\
\mathrm{ml} / \mathrm{m}^{2} / 24 \text { hours } \\
\text { Serum creatinine (mmol } / \mathrm{l} \text { ) } \\
>0.15 \text { (age day } 1-30 \text { ) } \\
\quad>0.04 \text { (age } 1-12 \text { months) } \\
>0.05 \text { (age } 1-4 \text { years) } \\
>0.06 \text { (age } 5-10 \text { years) } \\
>0.1 \text { (age }>10 \text { years) }\end{array}$ \\
\hline Hepatic & $\begin{array}{l}\text { Presence of three or more of the following } \\
\text { INR } \\
>1.7 \text { (day } 1-4) \\
>1.5 \text { (day } 5-29) \\
>1.3(>30 \text { days) } \\
\text { In absence of warfarin anticoagulation } \\
\text { AST }>100 \mathrm{U} / 1 \\
\text { Serum albumin: } \\
<23 \mathrm{~g} / 1 \text { (age }<12 \text { months) } \\
<30 \mathrm{~g} / 1 \text { (age }>12 \text { months) } \\
\text { Conjugated bilirubin }>10 \mathrm{mmol} / 1\end{array}$ \\
\hline Haemostasis & $\begin{array}{l}\text { Presence of two or more of the following: } \\
\text { Leucocytes }<1 \times 10^{9} / 1 \\
\text { Platelets }<20 \times 10^{9} / 1 \\
\text { INR } \\
>1.7 \text { (age day } 1-4) \\
>1.5 \text { (age day } 5-29) \\
>1.3(>30 \text { days) } \\
\text { In absence of warfarin anticoagulation } \\
\text { D-dimers }>0.25 \\
\text { APTT (sec) } \\
\text { Premature neonates } \\
>80 \text { (day } 1) \\
>75 \text { (day } 5) \\
>65 \text { (day } 30) \\
>50 \text { (>day } 180) \\
\text { Term infants } \\
>60 \text { (day } 1) \\
>55 \text { (day } 30) \\
>50 \text { (>day } 180 \text { ) } \\
\text { In absence of heparin anticoagulation }\end{array}$ \\
\hline Brain & Glascow motor score $<4$ (at any one point in the day in absence of sedation) \\
\hline
\end{tabular}

$\mathrm{A}-\mathrm{aDO}_{2}=$ alveolar-arterial oxygen tension difference; $\mathrm{APTT}=$ activated partial thromboplastin time; AST = asparate aminotransferase $\mathrm{INR}=$ international normalised ratio; $\mathrm{PaCO}_{2}=$ arterial oxygen tension.
RELATIONSHIP OF NO METABOLITES TO SURVIVAL IN SEPSIS

There were 21 children who survived and nine who died of the 30 children with sepsis in the series. Two children died within 12 hours of admission to intensive care. The seven other deaths occurred between two and 30 days after admission. There was no difference in the AUC for serum nitrogen oxide concentrations over the first 48 hours between those who survived (2189 $\mu \mathrm{mol}$, interquartile range 11774085) and those who died (3377 $\mu \mathrm{mol}$, interquartile range 2588-3641), MannWhitney, $p=0.24$. Nor were there any significant differences at admission, 12, 24, or 48 hours in serum concentrations of nitrogen oxides between survivors and deaths (see table 3).

When all subjects were considered there was a non-significant rise in median nitrogen oxide concentrations from the time of admission to 12 hours after, and a subsequent fall to admission levels by 24 hours (fig 3). Between each of the four time points measured, however, there were no statistically significant differences in median nitrogen oxide concentrations (Kruskal-Wallis test, $\mathrm{p}=0.61$ ). There was a similar non-significant increase in serum nitrogen oxides from admission to 12 hours in both survivors, and those who died.

In the two children who died within 12 hours of admission the serum concentrations of $\mathrm{NO}$ metabolites were not significantly different to other admission levels. One child with pneumococcal septic shock had a cardiac arrest soon after admission, and had an admission level of $29.3 \mu \mathrm{mol} / 1$, the lowest admission value of any patient who died. The other child had Staphylococcus aureus endocarditis and septic shock and had an admission level of 60.5 $\mu \mathrm{mol} / 1$.

\section{RELATIONSHIP OF NO METABOLITES TO ORGAN} SYSTEM FAILURE

Of the 28 survivors to 48 hours, 17 (61\%) had developed one or more organ systems failing and $10(36 \%)$ had failure of three or more organ systems. When children with one or more organ systems failing are compared with those with no organ failure, the difference in AUC for combined serum nitrate and nitrite was significant: no organ systems failing, median (interquartile range) 1259 (10762189); one or more systems failing: 3377 (2399-4174), (Mann-Whitney, $\mathrm{p}=0.0028$ ) (see figs 2 and 3).

When the data were analysed according to the numbers of organ systems failing at 48 hours, there was a weak positive relationship. The only difference in nitrogen oxide concentrations in patients subgrouped according to the number of organ systems failing at 48 hours was between those with no organ failure and those with one organ failing (Kruskal-Wallis test of equality of proportions, $p=0.03$, Sidak test for multiple comparisons, 0.041) (see fig 4). There were no differences between patients who had more than one organ system failing and those with none, although the numbers in
Whitney, $\mathrm{p}=0.0054)$. There was, how substantial overlap between the two groups (see fig 1). 


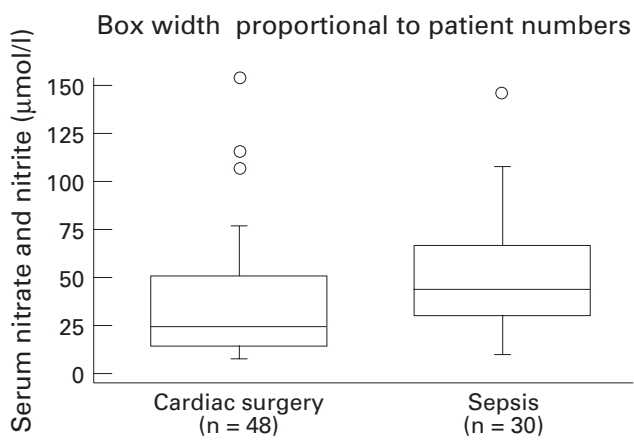

Figure 1 Box and whisker plot showing the serum concentrations of combined nitrate and nitrite in children with septic shock and presenting for elective cardiac surgery. There was a significant difference between the two groups (Mann-Whitney, $p=0.005$ ). The horizontal line in the box is the median value; the box extends to the interquartile range (25-75th centile); and the whiskers to the next closest values.

each group when patients were subgrouped as such were small.

RELATIONSHIP OF NO METABOLITES TO MARKERS OF PERFUSION FAILURE

We have previously shown that the earliest predictor of outcome in this group of patients was blood lactate at 12 hours after admission ( $\mathrm{T}$ Duke et al, submitted for publication). By 24 hours $\mathrm{DCO}_{2}$ and mean arterial pressure also predicted survival. In this present study we found no association between blood lactate, $\mathrm{DCO}_{2}$, or mean arterial pressure and AUC of combined serum nitrate and nitrite $\left(r^{2}=0.06\right.$, $\mathrm{p}=0.126 ; r^{2}=0.06, \mathrm{p}=0.435 ;$ and $r^{2}=0.08$, $\mathrm{p}=0.158$, respectively). Nor were there any associations between nitrogen oxides and gastric $\mathrm{pHi}\left(r^{2}=0.02, \mathrm{p}=0.637\right)$, or nitrogen oxides and the base deficit $\left(r^{2}=0.01, \mathrm{p}=0.252\right)$.

\section{RELATIONSHIP OF NO METABOLITES TO}

INOTROPIC SUPPORT

By 48 hours 11 of the 28 survivors to two days (39\%) continued to receive catecholamine inotropic support of their circulation (in excess of $5 \mu \mathrm{g} / \mathrm{kg} / \mathrm{min}$ of dopamine). Of those not requiring inotropes, $65 \%$ were free of organ system failure, while of those receiving inotropes at 48 hours $100 \%$ had two or more organ systems failing two days after admission. Seventy one per cent of the deaths occurred in the group still receiving inotropes at 48 hours, while $88 \%$ of children not receiving inotropes at 48 hours survived. There was no relationship, however, between the requirement for inotropic support at 48 hours and the level of serum NO metabolites, either when analysed using the AUC over 48 hours (Mann-Whitney test, $\mathrm{p}=0.57)$, or concentrations at any of the 4 time points, particularly at 48 hours $(p=0.60)$.

Table 2 Clinical details of 30 children with sepsis syndrome or septic shock

\begin{tabular}{|c|c|c|c|c|c|c|}
\hline No & $\begin{array}{l}\text { Age } \\
\text { (months) }\end{array}$ & Sex & Organism isolated & $\begin{array}{l}\text { Inotropes at } 48 \text { hours } \\
(\mu \mathrm{g} / \mathrm{kg} / \mathrm{min})\end{array}$ & Survived/died & $\begin{array}{l}\text { Organ system failure at } 48 \\
\text { hours }\end{array}$ \\
\hline 1 & 3.3 & $\mathrm{~F}$ & $N$ meningitidis & $\begin{array}{l}\text { Dopamine: } 2.5 \\
\text { Noradrenaline: } 0.2\end{array}$ & Survived & 2 \\
\hline 2 & 0.03 & M & $\begin{array}{l}\text { Group A } \\
\text { streptococcus }\end{array}$ & Dopamine:5 & Died & 3 \\
\hline 3 & 4.3 & $\mathrm{~F}$ & Pneumococcus & $\begin{array}{l}\text { Dopamine: } 10 \\
\text { Dobutamine: } 7.5\end{array}$ & Died & 4 \\
\hline 4 & 11.3 & M & $C$ albicans & $\begin{array}{l}\text { Dopamine: } 5 \\
\text { Dobutamine: } 5 \\
\text { Adrenaline: } 0.8\end{array}$ & Died & 3 \\
\hline 5 & 8.4 & $\mathrm{~F}$ & $S$ Aureus & $\star$ & Died & $\star$ \\
\hline 6 & 10.2 & $\mathrm{~F}$ & $N$ meningitidis & 0 & Survived & 0 \\
\hline 7 & 3.9 & $M$ & $N$ meningitidis & 0 & Survived & 0 \\
\hline 8 & 14.0 & $M$ & Neutropenic colitis & 0 & Survived & 0 \\
\hline 9 & 11.0 & M & E coli & $\begin{array}{l}\text { Dobutamine: } 10 \\
\text { Adrenaline: } 0.2\end{array}$ & Died & 5 \\
\hline 10 & 15.0 & M & Pneumococcus & $\star$ & Died & * \\
\hline 11 & 1.1 & $M$ & No growth & $\begin{array}{l}\text { Dobutamine: } 5 \\
\text { Adrenaline: } 1.0 \\
\text { Noradrenaline:0.6 }\end{array}$ & Died & 4 \\
\hline 12 & 2.0 & M & $P$ aeruginosa & $\begin{array}{l}\text { Dobutamine: } 10 \\
\text { Noradrenaline: } 0.2\end{array}$ & Died & 4 \\
\hline 13 & 4.8 & $M$ & No growth & 0 & Survived & 0 \\
\hline 14 & 14.0 & $\mathrm{~F}$ & No growth & 0 & Survived & 2 \\
\hline 15 & 120.0 & $M$ & $S$ aureus & 0 & Survived & 0 \\
\hline 16 & 13.0 & $\mathrm{~F}$ & No growth & 0 & Survived & 0 \\
\hline 17 & 26.5 & $M$ & $C$ septicum & Dopamine: 10 & Survived & 3 \\
\hline 18 & 5.8 & $M$ & $N$ meningitidis & 0 & Survived & 0 \\
\hline 19 & 20.9 & M & $C$ septicum & $\begin{array}{l}\text { Dopamine: } 10 \\
\text { Noradrenaline:0.2 }\end{array}$ & Survived & 2 \\
\hline 20 & 17.5 & M & $N$ meningitidis & Dopamine:2.5 & Survived & 1 \\
\hline 21 & 4.8 & $\mathrm{~F}$ & Pneumococcus & 0 & Survived & 0 \\
\hline 22 & 17.7 & $M$ & $N$ meningitidis & 0 & Survived & 0 \\
\hline 23 & 16.5 & $M$ & $N$ meningiditis & 0 & Survived & 0 \\
\hline 24 & 223.0 & $M$ & Mixed organisms & Dopamine:2.5 & Died & 1 \\
\hline 25 & 189.0 & $\mathrm{~F}$ & Mixed organisms & Dopamine:5 & Survived & 3 \\
\hline 26 & 193.0 & M & $\begin{array}{l}\text { Group B } \\
\text { streptococcus }\end{array}$ & $\begin{array}{l}\text { Dopamine: } 5 \\
\text { Noradrenaline: } 0.3\end{array}$ & Survived & 4 \\
\hline 27 & 0.75 & M & $S$ mercasens & $\begin{array}{l}\text { Dopamine: } 5 \\
\text { Noradrenaline: } 0.2\end{array}$ & Survived & 4 \\
\hline 28 & 7.3 & $M$ & No growth & 0 & Survived & 0 \\
\hline 29 & 7.8 & M & $N$ meningitidis & 0 & Survived & 1 \\
\hline 30 & 6.8 & $\mathrm{~F}$ & $N$ meningitidis & 0 & Survived & 1 \\
\hline
\end{tabular}

$\star$ Died less than 12 hours after admission. $C$ albicans $=$ Candida albicans; $C$ septicum $=$ Clostridium septicum; $E$ coli $=$ Escherichia coli N meningitidis $=$ Neisseria meningitidis $; S$ aureus $=$ Staphycocccus aureus; $S$ mercasens $=$ Serratia mercasens. 
Table 3 Nitrogen oxide concentrations in children who died from and who survived septic shock

\begin{tabular}{llll}
\hline Time from admission & Survivors & Deaths & p Value \\
\hline Admission & $49.3(34.0$ to 64.7$)$ & $56.1(33.8$ to 78.5$)$ & 0.60 \\
12 hours & $57.2(41.7$ to 72.6$)$ & $72.4(39.0$ to 105.9$)$ & 0.32 \\
24 hours & $48.7(30.8$ to 66.6$)$ & $59.5(42.4$ to 76.6$)$ & 0.49 \\
48 hours & $57.4(39.5$ to 75.2$)$ & $60.2(45.7$ to 75.3$)$ & 0.85 \\
\hline
\end{tabular}

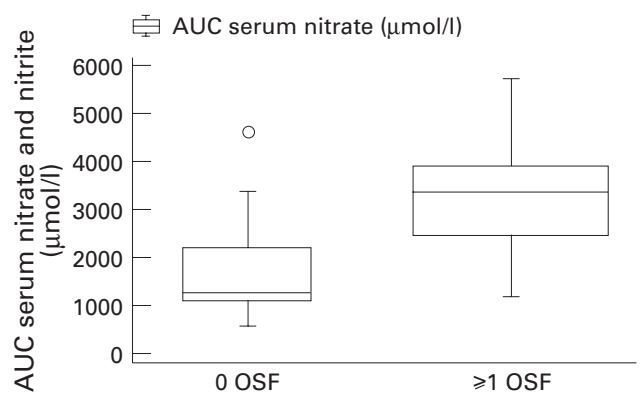

Figure 2 Graph showing AUC for serum nitrate and nitrite for the first 48 hours of admission to the intensive care unit for patients who at 48 hours had no residual organ dysfunction and those who had one or more organ systems failing (OSF). There was a significant difference between the NO metabolite concentrations when patients were subgrouped as either having no or one or more organ systems failing (Mann-Whitney, $p=0.0028$ ).

\section{RELATIONSHIP OF NO METABOLITES TO RENAL}

FUNCTION

We found no association between nitrogen oxide concentrations and renal function. There was no relationship between the area under the curve of $\mathrm{NO}$ metabolites and the area under the curve of serum creatinine $\left(r^{2}=0.07, \mathrm{p}=0.1\right)$. Nor was there a relationship between the change in serum creatinine from the time of admission to 48 hours, and the AUC nitrate and nitrite $\left(r^{2}=0.04, \mathrm{p}=0.157\right)$ (see fig 5). When patients were subgrouped according to the presence or absence of renal failure, based on the clinical definitions (in table 1), and not solely on serum creatinine, there was no difference in AUC nitrogen oxides (Mann-Whitney, $\mathrm{p}=0.12$ ), or in the serum concentration at 48 hours $(p=0.38)$.

\section{Conclusion and discussion}

This study confirms that there was increased activity of the L-arginine nitric oxide pathway, as measured by combined serum nitrate and nitrite levels, in children with sepsis syndrome and septic shock, at the time of intensive care unit admission, compared with a control group of non-septic children. These findings confirm those of Shi et al in neonates, ${ }^{9}$ and Wong et al, ${ }^{7}$ who found higher levels of serum nitrate and nitrite in children with sepsis syndrome than in controls. In the present study serum concentrations of nitrogen oxides were weakly, but positively, associated with illness severity, as judged by the presence or absence of organ system failure; but there was no association with mortality.

The AUC of nitrogen oxide concentrations was chosen as a summary measure because of the theory that activity of the L-arginine nitric oxide pathway in sepsis is biphasic. ${ }^{28}$ Early in sepsis endothelial constitutive NO synthase (c-NOS), the enzyme producing NO which mediates physiological vascular tone, will be active (at normal, increased, or possibly decreased levels). Four to 12 hours after the onset of systemic infection inducible NO synthase (i-NOS) is activated, producing relatively large amounts of NO. The duration of i-NOS activity in sepsis is unknown, but may be dependent on the duration of exposure to the NOS enzyme inducing stimulus. AUC may therefore be a more accurate reflection of NO activity than single measurements taken at different phases in the evolution of a patients illness.

Although serum concentrations of NO metabolites were higher in children with sepsis complicated by organ system failure, there was no identifiable biological gradient to the association. As the severity of organ failure increased from one to five systems, there was no change in AUC nitrogen oxides. Children who had four or five organ systems failing at 48 hours, and those who died, clearly had more severe disease than those with just one failed organ system, but this was not reflected in an increase in measurable $\mathrm{NO}$ activity.

We could find no relationship between ongoing inotropic support at 48 hours and the level of serum NO metabolites. This is contrary to the findings of Wong et al who found that serum nitrate and nitrite concentrations were positively associated with the noradrenaline dose required to reach the 50th centile of the mean arterial pressure for age in five children with sepsis. ${ }^{7}$ We did not measure, however, the true requirement for inotropes to maintain blood pressure or cardiac output, but rather the receipt of inotropes. The use of inotropes is determined by clinician prescribing practice, which does not always reflect patient need, and inotropes are not solely given to maintain blood pressure. We found no association between hypotension and serum nitrogen oxides. The approach by Wong et al probably better measures vascular hyporesponsiveness, ${ }^{7}$ which is the proposed mechanism for the association between high $\mathrm{NO}$ activity and reduced response to noradrenaline. However, our study suggests that children who required pharmacological support for prolonged circulatory instability did not have evidence of further increase of NO metabolites.

Unlike some other investigators ${ }^{15}$ we found no relationship between nitrate levels and renal function to explain the relationship of nitrogen oxide concentrations and sepsis severity. A deterioration in renal function over time was not associated with an increase in NO metabolite levels. It therefore seems unlikely that our findings of increased concentrations of $\mathrm{NO}$ metabolites in children with sepsis induced organ system failure can be attributed solely to renal dysfunction.

We conclude that the NO pathway is activated in sepsis in children, and that serum NO concentrations are associated with some indices of severity, but not other more important markers. This evidence suggests that factors other than, or in addition to, $\mathrm{NO}$ are important in the development of perfusion failure, and the detrimental consequences of 


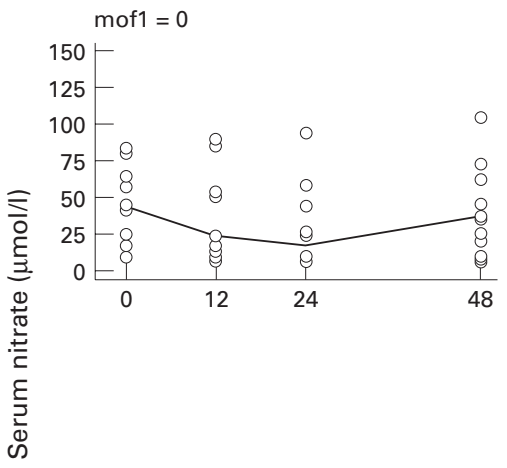

Time from admission to ICU in hours

Figure 3 Time course of combined nitrate and nitrite in children with sepsis not complicated by organ failure at 48 hours (mof $1=0$ ), those who had one or more organ systems failing at 48 hours $($ mof $1=1)$, and all 30 children $(n=30)$. Line passes through the median at the four time points. There was a significant difference in AUC between the two subgroups $(p=0.0028)(I C U=$ intensive care unit $)$.

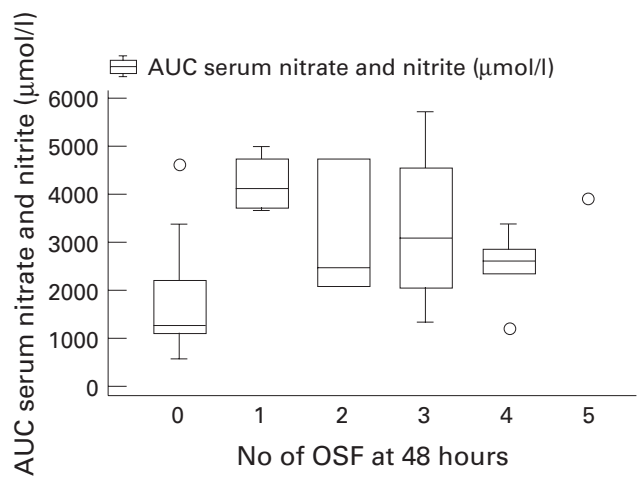

Figure 4 AUC for serum nitrate and nitrite over the first 48 hours of admission in 30 children with sepsis or septic shock according to the numbers of organ systems failing (OSF) at 48 hours after admission. There was a significant difference in NO metabolite concentrations between children with one and no organ systems failing, but no differences between any of the other subgroups (Kruskal-Wallis test, $p=0.03$, Sidak test for multiple comparisons between one and no organ systems failing, $p=0.041$ ).

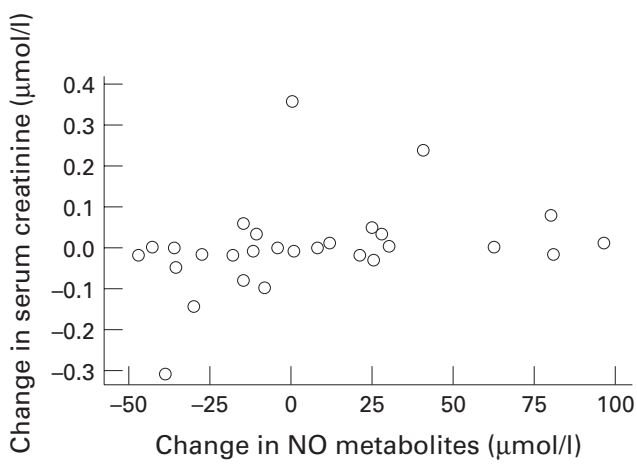

Figure 5 Graph showing the change in serum creatinine over the first 48 hours of sepsis and the change in nitrogen oxides. Those children who had a worsening of renal function after admission were not more likely to have an increase in serum concentrations of nitrate and nitrite.

sepsis syndrome. The involvement of $\mathrm{NO}$ in sepsis is likely to be multifaceted. It may have a protective role in maintaining perfusion by microvascular vasodilatation, and may be cyto-

\section{Key messages}

- Serum NO metabolites were higher in children with sepsis than in non-septic controls

- There was only a limited relationship between the severity of organ system failure and serum NO metabolite concentrations

- There was no difference in NO metabolite concentrations between survivors and those who died

- There was no relationship between serum NO metabolite concentrations and clinically important markers of perfusion or inotropic requirements

toxic to invading organisms. ${ }^{29}{ }^{30} \mathrm{NO}$ also may prevent inflammatory cell mediated host tissue damage by the inhibition of leucocyte activation. ${ }^{31}{ }^{32}$ On the other hand, NO may be cytotoxic to host cells, either directly, or by the interaction with oxygen derived radicals and the generation of highly toxic molecules, such as peroxynitrate. ${ }^{33}$ Further work will be required to determine if the augmentation or inhibition of $\mathrm{NO}$ production in sepsis in children is of benefit.

The study was supported in part by the Royal Children's Hospital Research Foundation and the National Health and Medical Research Council of Australia. The authors thank Ms Rosalind Romes for technical assistance.

1 Moncada S, Higgs A. The L-arginine-nitric oxide pathway. N Engl f Med 1993;329:2002-12.

2 Preiser J-C, Lejeune P, Roman A, et al. Methylene blue administration in septic shock: a clinical trial. Crit Care Med 1995;23:259-64

3 Lorente JA, Landin L, Renes E, et al. Role of nitric oxide in the hemodynamic changes of sepsis. Crit Care Med 1993;21:759-67.

4 Petros A, Lamb G, Leone A, Moncada S, Bennett D, Vallance P. Effects of a nitric oxide synthase inhibitor in Vallance P. Effects of a nitric oxide synthase inhibitor in
humans with septic shock. Cardiovasc Res 1994;28:34-9.

5 Daemen-Gubbels CRGH, Groenveld PHP, Groenveld ABJ, van Kamp GJ, Bronsveld W, Thijs LG. Methylene blue increases myocardial function in septic shock. Crit Care Med 1995;23:1363-70.

6 Hata JS, Dellinger RP. Nitric oxide inhibition in the treatment of septic shock. Crit Care Med 1995;23:1621-4. 7 Wong HR, Carcillo JA, Burchart G, Shah N, Janosky JE. Increased serum nitrite and nitrate concentrations in children with sepsis syndrome. Crit Care Med 1995;23:83542.

8 Ochoa JB, Udekwu AO, Billiar TR, et al. Nitrogen oxide levels in patients after trauma and during sepsis. Ann Surg 1991;214:621-6.

9 Shi Y, Li H-1, Shen C-K, et al. Plasma nitric oxide levels in newborn infants with sepsis. F Pediatr 1993;123:435-8.

10 Kilbourn RG, Belloni P. Endothelial cell production of nitrogen oxides in response to interferon gamma in combination with tumour necrosis factor, interleukin-1, or endotoxin. I Natl Cancer Inst 1990;82:772-6.

11 Brady AJB, Poole-Wilson PA. Circulatory failure in septic shock. Nitric oxide: too much of a good thing? Br Heart $\mathcal{F}$ 1993;70:103-5.

12 Scabo CS, Mitchell JA, Thiemermann C. Nitric oxide mediated hyporeactivity to norepinephrine precedes nitric oxide synthase induction in endotoxin shock. BrF Pharmacol 1993;108:786-92.

13 Julou-Schaeffer G, Gray GA, Fleming I, Schott C, Parratt $\mathrm{JR}$, Stoclet J-C. Loss of vascular responsiveness induced by endotoxin involves L-arginine pathway. Am f Physiol 1990; 259:H1038-43.

14 Friedman G, Berlot G, Kahn R, Vincent J-L. Combined measurements of blood lactate concentrations and gastric intramucosal $\mathrm{pH}$ in patients with severe sepsis. Crit Care Med 1995;23:1 184-93.

15 Mackenzie IMJ, Young JD, Garrard CS. Serum nitrates as markers of postoperative morbidity. Lancet 1994;344:410.

16 Bone RC, Fisher CJ, Clemmer TP, et al. A controlled clinical trial of high-dose methylprednisolone in the treatment of severe sepsis and septic shock. N Engl f Med 1987;317: 653-8. 
17 Blumenthal S, Epps RP, Heavenrich R. Report on the taskforce on blood pressure control in children. Pediatrics 1977;59:802-3.

18 Jacobs RF, Sowell MK, Moss MM, Fiser DH. Septic shock in children: bacterial etiologies and temporal relationships. Pediatr Infect Dis $\mathcal{F}$ 1990;9:196-200.

19 Krafte-Jacobs B, Carver J, Wilkinson JD. Comparison of gastric intramucosal $\mathrm{pH}$ and standard perfusional measurements in pediatric septic shock. Chest 1995;108:220-5.

20 Matthews JNS, Altman DG, Campbell MJ, Royston P. Analysis of serial measurements in medical research. $B M \mathcal{F}$ 1990;300:230-5.

21 Andrew M, Paes B, Milner R. The development of the human coagulation system in the fullterm infant. Blood 1987;70:165-72.

22 Andrew M, Paes B, Milner R. Development of the coagulation system in the healthy premature infant. Blood 1988;72: 1651-7.

23 Andrew M, Paes B, Johnston M. Development of the hemostatic system in the neonate and young infant. Am $\mathcal{F}$ Pediatr static system in the neonate and
Hematol Oncol 1990;12:95-104.

24 Department of Clinical Biochemistry, Royal Children's Hospital. Reference ranges in clinical biochemistry. Melbourne: Educational Resources Centre, Royal Children's Hospital, 1993: 2-23.

25 Shann F. Drug doses. Melbourne: Collective Pty Ltd, 1996: 65.
26 Knaus WA, Draper EA, Wagner DP, Zimmerman JE. Prognosis in acute organ-system failure. Ann Surg 1985;202: 685-93

27 Feelisch M. The biochemical pathways of nitric oxide formation from nitrovasodilators: appropriate choice of exogenous NO donors and aspects of preparation and handling of aqueous NO solutions. F Cardiovasc Pharmacol 1991;17:S25-33.

28 Szabo C. Alterations in nitric oxide production in various forms of circulatory shock. New Horizons 1995;3:2-32.

29 De Groote MA, Fang FC. NO inhibitions: antimicrobial properties of nitric oxide. Clin Infect Dis 1995;21:S162-5.

30 Malawista SE, Montgomery RR, Van Blaricom G. Evidence for reactive nitrogen intermediates in killing of staphylococci by human neutrophil cytoplasts. F Clin Invest 1992;90: 631-6.

31 Kubes P, Suzuki M, Granger DN. Nitric oxide: an endogenous modulator of leukocyte adhesion. Proc Natl Acad Sci U S A 1991;88:4651-5.

32 Kanwar S, Kubes P. Nitric oxide is an antiadhesive molecule for leukocytes. New Horizons 1995;3:93-103.

33 Beckman JS, Beckman TW, Chen J. Apparent hydroxyl radical production by peroxynitrite: implications for endothelial injury from nitric oxide and superoxide. Proc Natl Acad Sci U S A 1990;87:1620-4.

\section{The spread of obesity}

You don't have to spend long in the United States to be impressed by the Bermuda-bursting buttocks of a very noticeable proportion of the population. Dine at any American restaurant and you are faced with massive food portions which make the 'doggy bag' a routine requirement. The increase in obesity in both adults and children in the USA over the last 30 years or so is well documented. For many energy intake is clearly well ahead of energy output; some hope that 'they' (the scientists) will find the answer through research into the genetics and molecular basis of obesity and its consequences, others favour an educational approach promoting less food and more activity. A study in Cincinnati, Ohio (Orit Pinhas-Hamiel and colleagues, fournal of Pediatrics 1996;128:608-15) has shown one potential serious consequence of childhood obesity.

Previous studies have shown non-insulin dependent diabetes mellitus (NIDDM) to be about 2 or $3 \%$ of childhood diabetes. In Cincinnati the proportion in newly diagnosed child diabetics rose from $4 \%$ in the years $1982-91$ to $16 \%$ in 1994 . The incidence of NIDDM in adolescents was 0.7 per 100000 per year in 1982 and 7.2 per 100000 per year in 1994 and currently one in three 10 to 19 year olds presenting with diabetes has NIDDM. The mean age at onset of child or adolescent NIDDM was 13.8 years and the mean body mass index at presentation was 38. Sixty five per cent of patients had a first degree relative with NIDDM. At the time of diagnosis of NIDDM $17 \%$ were hypertensive and $6 \%$ had sleep apnoea.

In the 1970 s British paediatricians were much concerned about childhood obesity and its consequences but lack of success in its management cooled many an enthusiasm. In 1830 Metternich said, 'When Paris sneezes Europe catches cold'. It is to be hoped the American obesity virus doesn't blow this way. I've a feeling obesity is set to be a growing topic again.

ARCHIVIST 